\title{
Crop Load Influences Fruit Quality, Nutritional Balance, and Return Bloom in 'Honeycrisp' Apple
}

\author{
Sara Serra \\ Tree Fruit Research and Extension Center, Washington State University, \\ Wenatchee, WA 98801; and Department of Horticulture, Washington State \\ University, Pullman, WA 99164
}

\section{Rachel Leisso}

Tree Fruit Research and Extension Center, Washington State University, Wenatchee, WA 98801; Department of Horticulture, Washington State University, Pullman, WA 99164; and Tree Fruit Research Laboratory, Agricultural Research Service, U.S. Department of Agriculture, Wenatchee, WA 98801

\section{Luca Giordani, Lee Kalcsits, and Stefano Musacchi ${ }^{1}$ \\ Tree Fruit Research and Extension Center, Washington State University, Wenatchee, WA 98801; and Department of Horticulture, Washington State University, Pullman, WA 99164}

Additional index words. apple, crop load, $I_{\mathrm{AD}}$, fruit quality parameters, fruit size, nutrition

\begin{abstract}
The apple variety, 'Honeycrisp' has been extensively planted in North America during the last two decades. However, it suffers from several agronomic problems that limit productivity and postharvest quality. To reduce losses, new information is needed to better describe the impact of crop load on productivity and postharvest fruit quality in a desert environment and the major region where 'Honeycrisp' expansion is occurring. Here, 7-year-old 'Honeycrisp' trees on the M9Nic29 rootstock $(2.5 \times 0.9 \mathrm{~m})$ were hand thinned to five different crop loads [from 4.7 to 16.0 fruit $/ \mathrm{cm}^{2}$ of trunk cross-sectional area (TCSA)] to compare fruit quality, maturity, fruit size, elemental concentration, and return bloom. Fruit size distribution was affected by crop load. Trees with the highest crop load $\left(16 \mathrm{fruit} / \mathrm{cm}^{2}\right)$ produced smaller fruit. Index of absorbance difference $\left(I_{\mathrm{AD}}\right)$ measurements (absorption difference between 670 and $720 \mathrm{~nm}$ ), a proxy indicator of the chlorophyll content below the skin of fruit measured by a DA-meter, were made shortly after harvest (T0) and after 6 months of storage (T1). Fruit from the trees with the lowest crop load had lower $I_{\mathrm{AD}}$ values indicating advanced fruit ripeness. The comparison between the $I_{\mathrm{AD}}$ classes at $\mathrm{TO}$ and T1 showed that fruit belonging to the lowest $I_{\mathrm{AD}}$ class had significantly higher redblushed overcolor percentage, firmness, dry matter, and soluble solid content than those in the "most unripe" class (highest $I_{\mathrm{AD}}$ readings) regardless of crop load. The percentage of blushed color, firmness, titratable acidity (TA), soluble solids content, and dry matter were all higher in the lowest crop loads at both $\mathrm{T} 0$ and $\mathrm{T} 1$. Fruit calcium (Ca) concentration was lowest at the lowest crop load. The $(\mathrm{K}+\mathrm{Mg}+\mathrm{N})$ : Ca ratio decreased as crop load increased until a crop load of $11.3 \mathrm{fruit} / \mathrm{cm}^{2}$, which was not significantly different from higher crop loads. For return bloom, the highest number of flower clusters per tree was reported for 4.7 fruit $/ \mathrm{cm}^{2}$ crop load, and generally it decreased as crop load increased. Here, we highlight the corresponding changes in fruit quality, storability, and elemental balance with tree crop load. To maintain high fruit quality and consistency in yield, careful crop load management is required to minimize bienniality and improve fruit quality and storability.
\end{abstract}

The apple variety, 'Honeycrisp', is a premium fresh fruit marketplace variety (Embree et al., 2007; Rosenberger et al., 2004) selected in Minnesota. As such, it is

Received for publication 2 Oct. 2015. Accepted for publication 13 Jan. 2016.

We thank Celeste Wheeler for their helpful technical assistance.

${ }^{1}$ Corresponding author. E-mail: stefano.musacchi@ wsu.edu. well adapted to northern climatic conditions (Luby and Bedford, 1990). 'Honeycrisp' is a profitable apple for growers and, for this reason, the acreage is expanding from cold to warmer areas (Nichols and Wright, 2003) including Washington State. Orchard management and the production of high quality for 'Honeycrisp' fruit can be challenging, especially in hot climate areas like Washington State. Washington's climate varies greatly from west to east. In the Columbia Basin, one of the main area for apple production, the climate is semiarid (http://www.wrcc.dri. edu). Early fruit production before the trees have developed a complete canopy can permanently limit the final tree size and consequently, can impact future productivity (Castro et al., 2015). Crop load management is particularly important for 'Honeycrisp' because it can limit inconsistent annual flowering and fruit set (Embree et al., 2007), improve fruit quality (Baugher and Schupp, 2010), and decrease susceptibility to storage disorders (Robinson and Watkins, 2009). 'Honeycrisp' has exhibited an extreme predisposition to overcropping, therefore, is susceptible to biennial bearing (Crassweller et al., 2005; Embree and Nichols, 2005; Robinson and Watkins, 2003; Wright et al., 2006), especially when thinning is completed too late (Pellerin et al., 2011, 2012). Thinning is a common agronomical practice to optimize crop load to improve fruit size and quality as well as reducing biennial bearing (Dennis, 2000; Link, 2000; Wertheim, 2000). Thinning affects the cell number and fruit size (Bain and Robertson, 1951), and is considered effective within 4 to 12 weeks after full bloom, while its efficacy is cultivar dependent (Bergh, 1990; Denne, 1960).

Both crop load and warmer climate conditions can affect the balance of nutrients in the fruits and leaves and, subsequently, affects postharvest fruit quality and postharvest susceptibility to storage disorders. Young 'Honeycrisp' orchards are susceptible to bitter pit and symptoms can appear before harvest or during storage (Rosenberger et al., 2004). High vegetative vigor can lead to transpiration imbalances and less $\mathrm{Ca}$ being allocated to the developing fruit (Wünsche and Ferguson, 2005). These effects may be further magnified in a hot, desert climate where transpiration pressures are greater. The amount of affected fruit can increase dramatically in situations of excessive vigor and/or low crop loads. Bitter pit is associated with low $\mathrm{Ca}$ concentration in fruit and the elemental balance between $\mathrm{Ca}$, potassium $(\mathrm{K})$, magnesium $(\mathrm{Mg})$, and nitrogen $(\mathrm{N})$. High concentrations of $\mathrm{K}, \mathrm{Mg}$, and $\mathrm{N}$ are associated with an increase in the percentage of fruit lost to bitter pit. Crop load has a strong effect on fruit size (Embree et al., 2007). Fruit size can also be influenced by low soil $\mathrm{pH}$, boron deficiency, and environmental stress such as drought (Faust and Shear, 1968; Ferguson and Watkins, 1989; Rosenberger et al., 2004). Bangerth (1979) and Wünsche and Ferguson (2005) reported that larger fruit have lower $\mathrm{Ca}$ concentrations suggesting that high fruit growth rates in late stages of fruit development can lead to fruit $\mathrm{Ca}$ deficiencies. High crop loads can limit tree vigor and fruit size and can decrease the incidence of this physiological disorder. However, it is well known that a high crop load can reduce size, color appearance, lower flesh firmness, lower sugars, and acidity of fruits (Embree et al., 2007; Hampson and Kemp, 2003) in addition to return bloom the following year. Crop load can also affect the photosynthesis in apple tree (Palmer et al., 1997) and dry matter 
production and carbon allocation (Avery, 1975; Heim et al., 1979; Palmer, 1992; Palmer et al., 2010). The effect of crop load on 'Honeycrisp' postharvest quality has not been widely reported in Washington State.

Here, the main objective was to determine the impact of different crop loads on fruit quality, storability, nutritional balance, and return of bloom in 'Honeycrisp' in a desert environment. Our hypothesis was that lower crop loads would promote more return bloom and increase fruit quality for 'Honeycrisp' grown in warmer climates. Additionally, our preliminary work indicated that a nondestructive approach using the DA-meter (Ziosi et al., 2008) can be used to predict quality attributes of pome fruit in storage. Additionally, we sought to further test the application of DA-meter for 'Honeycrisp' fruit maturity and storability assessments. Understanding the impact of tree crop load on mineral nutritional balance in combination with fruit quality, ripening, and storability can help to optimize tree management and better identify optimum crop loads suitable for 'Honeycrisp' grown in warmer climates.

\section{Materials and Methods}

Field conditions. The experimental field was located in Naches, WA $\left(46^{\circ} 43^{\prime} 23.01^{\prime \prime} \mathrm{N}\right.$, $\left.120^{\circ} 40^{\prime} 26.07^{\prime \prime} \mathrm{W}\right)$. Seven-year-old apple trees cv. Honeycrisp ${ }^{\mathrm{TM}}$ grafted on M9-NIC29 were trained to a vertical axis with a planting density of $2.5 \times 0.9 \mathrm{~m}$ (4444 trees/ha). The orchard was watered with drip irrigation and mulched along the rows with coarse bark chips. Soil in the trial location was collected (at $20 \mathrm{~cm}$ from the trunk under the mulch) at two depths $(0-30$ and $30-60 \mathrm{~cm})$ pooling together three rows. Soil was classified as a loam (U.S. Department of Agriculture texture) with $50 \%$ sand, $12 \%$ clay, and $38 \%$ silt in the first $30 \mathrm{~cm}$ of soil sampling, while $40 \%$ sand, $14 \%$ clay, and $46 \%$ silt in $30-60 \mathrm{~cm}$ depth. pH was 7.7 and 7.2 at the two depths, respectively, which is a little higher than conventional apple orchards in the same region of Washington (Glover et al., 2000). Soil analysis did not indicate abnormal nutrient or $\mathrm{pH}$ imbalances and fertility was managed with a combination of fertigation applied with drip irrigation and foliar treatments.

Tree size was variable within the orchard. To limit the effect of tree-to-tree variation on fruit productivity and quality during tree sample selection, trunk cross-sectional area was measured for 40 trees that ranged from 5.2 to $10.0 \mathrm{~cm}^{2}$ (Supplemental Fig. 1). Fifteen homogeneous trees (average height $314 \mathrm{~cm}$ ) were selected with a trunk cross-sectional area between 7 and $9 \mathrm{~cm}^{2}$ (measured at $15 \mathrm{~cm}$ from the grafting point). In 2014, full bloom in the experimental block occurred during the last week of April. At the end of June, sample trees were hand thinned to five different crop load targets; 30-40, 50-65, 75-85, 90-100, and 125-135 fruit/tree, which at harvest averaged $34,56,84,95$, and 130 fruit/tree, respectively. Converting to fruit/TCSA $\mathrm{cm}^{2}$ crop was equal to $4.7,7.5,11.3,12.5$, and 16.0 fruit/TCSA $\mathrm{cm}^{2}$, from low to high crop loads described above, respectively. These were the actual number of fruit remaining on the tree at harvest and, therefore, crop loads were not evenly distributed between treatments.

Fruit analysis. Fruit were harvested in a single picking ( 1 week before commercial harvest) on 28 Aug. 2014. The number of fruits and yield ( $\mathrm{kg} /$ tree) were measured for each tree. Yield per tree and total number of fruit per tree were combined with trunk crosssectional area to calculate yield efficiency $\left(\mathrm{kg} / \mathrm{cm}^{2}\right)$ and crop load (fruit $\left./ \mathrm{cm}^{2}\right)$, respectively. Fruit from each tree was categorized into fruit size classes $(<55,55-59,60-64$, $65-69,70-74,75-79,80-84,85-89$, and $\geq 90 \mathrm{~mm}$ ) using an apple liner sizer (Turoni, Italy). Fruit belonging to the fruit size range between 75 and $84 \mathrm{~mm}$ were collected for further storage and quality analysis to minimize the effect of differences in fruit size distribution on quality and storability. Fruit were then placed in a $0^{\circ} \mathrm{C}$ regular atmosphere cold storage room. Quality and maturity assessments included $I_{\mathrm{AD}}$ (a proxy indicator of the chlorophyll content below the skin of fruit), mass (g), maximum height, maximum width, foreground (darkest red), background color and percentage of red-blushed surface (estimated as the percentage of red overcolor on the total apple surface), flesh firmness, soluble solids concentration (SSC), starch index (SI), dry matter, TA, and internal ethylene concentration (IEC).

One month after harvest (T0), $I_{\mathrm{AD}}$ was measured using a DA-meter (Sinteleia, Bologna, Italy), a handheld device that measures chlorophyll concentration several millimeters (Ziosi et al., 2008) into the flesh of fruit providing the $I_{\mathrm{AD}}$. This device has been tested as a maturity indicator in 'Honeycrisp' (DeLong et al., 2014). $I_{\mathrm{AD}}$ was measured at the equatorial region on both the sun and shade side of the fruit, and the mean calculated and used for the measured value. $I_{\mathrm{AD}}$ assessments at harvest were used to categorize fruit into one of three classes: $<0.60$, $0.60-0.99$, and $>1.00$ (where possible) according to the reference data (DeLong et al., 2014). Fruit were divided into two similar batches: half of the fruit were assessed for quality and maturity after 1 month of regular air storage at $0{ }^{\circ} \mathrm{C}$ (T0, Sept. 2014) and the other half were assessed for quality and maturity after 6-month storage (T1, Feb. 2015) where $I_{\mathrm{AD}}$ was measured again for the stored fruit.

Foreground (red-blushed overcolor) and background color was recorded as CIE $L^{*} a * b^{*}$ with a Minolta colorimeter (Minolta CR-300 Chroma meter, Konica Minolta, Tokyo, Japan). L*, lightness coefficient, ranges from black $=0$ to white $=$ $100, a^{*}>0$ is red, $a^{*}<0$ is green, $b^{*}>0$ is yellow, and $\mathrm{b}^{*}<0$ is blue. Hue angle $\left(h^{\circ}\right)$ and chroma $\left(C^{*}\right)$, parameters used to describe color that is closest to human perception (Alcobendas et al., 2012), were calculated per McGuire (1992) and Núñez-Delicado et al. (2005).
Firmness was tested on two pair sides (sun/shade) of each fruit using a Fruit Texture Analyzer (Guss Manufacturing Ltd., Strand, South Africa) equipped with a $10 \mathrm{~mm}$ probe. Firmness $\left(\mathrm{kg} \cdot \mathrm{cm}^{-2}\right)$ was calculated as the average of the two measures. For SSC, a single longitudinal slice was removed from the fruit, and juiced by a handheld press onto a pocket refractometer (PAL-1; Atago U.S.A. Inc., Bellevue, WA) to make the reading. Data were recorded as Brix. SI was performed using a $1-\mathrm{cm}$ thick slice was taken from the equatorial region of the fruit and sprayed with Lugol's solution (15 g. $\mathrm{L}^{-1}$ potassium iodide and $6 \mathrm{~g} \cdot \mathrm{L}^{-1}$ iodine) using a handheld spray bottle. Assessments were made after at least $5 \mathrm{~min}$ incubation and no later than $30 \mathrm{~min}$ after application. SI was visually rated on a 1 to 6 scale according to the Washington Tree Fruit Research Commission SI for 'Honeycrisp' (Hanrahan, 2012) ( $1=$ no hydrolysis, all tissue stained black; $6=$ hydrolysis complete, tissue white). The same person rated fruit starch throughout the experiment. Dry matter was assessed on five equatorial slices for each combination of crop load and $I_{\mathrm{AD}}$ class by taking the fresh weight of the peeled slices (after removing the core) and then weighing them again after drying in an oven at $60{ }^{\circ} \mathrm{C}$ for $\approx 7 \mathrm{~d}$ (until weight was stable).

IEC, measured in the fruit core, were determined by piercing the calyx end of the fruit with a wide-bore needle coupled with a septum. Gas sample of $0.5 \mathrm{~mL}$ taken from the fruit core was injected into a 5890A GCFID (Hewlett Packard, Avondale, PA) equipped with a $45 \mathrm{~cm} \times 2 \mathrm{~mm}$ stainless steel column packed with 80/100 mesh Poropak Q (Supelco, Bellafonte, PA). The 5890 GC-FID was calibrated with $0.5 \mathrm{~mL}$ gas containing $10.0 \mathrm{ppm}$ authentic ethylene standard (Scotty Analyzed Gasses, Bellafonte, PA). The temperature of the injector, oven, and detector were 100,60 , and $300{ }^{\circ} \mathrm{C}$, respectively. Ten fruit were measured from each crop load and $I_{\mathrm{AD}}$ class combination.

Juice for TA and $\mathrm{pH}$ assessments was prepared using a Juiceman Juicer (Juiceman, Middleton, WI). Cubed chunks of fruit $\approx 3 \mathrm{~cm}^{3}$ were removed from both the top and bottom halves of the fruit from both sun and shade sides; fruit were divided equally into three replications per crop load and $I_{\mathrm{AD}}$ class combination. Juice was frozen immediately following juicing. Five milliliter samples were thawed for $1 \mathrm{~h}$ before $\mathrm{pH}$ and TA assessment with a Tiamo titrator (Metrohm AG, Herisau, Switzerland) using a modified Metrohm titrimetric method. Potassium hydroxide $(0.1 \mathrm{~N})$ was used as the titrant to end point $\mathrm{pH}$ 8.2. Data recording and equipment control were automated by Tiamo software version 1.2.41. Acidity data are expressed as TA units (\% malic acid).

Fruit nutritional analysis. Samples were taken from the equatorial region of fruit that was stored for 6 months to analyze for $\mathrm{Ca}, \mathrm{K}$, $\mathrm{Mg}$, and $\mathrm{N}$. The skin and cores were removed and the samples were dried at $60^{\circ} \mathrm{C}$ for $7 \mathrm{~d}$. Once dry, samples were ground to a fine 
Table 1. Effect of crop load on number of fruit/trunk cross-sectional area (TCSA), yield per tree, average fruit weight (g) and yield efficiency (kg/TCSA) for 'Honeycrisp' apple fruit grown in the northwest United States.

\begin{tabular}{lccccc}
\hline Target no. of fruit per tree & No. of fruit per tree & No. of fruit/ $\mathrm{cm}^{2}$ TCSA & Yield/tree $(\mathrm{kg})$ & Fruit wt $(\mathrm{g})$ & Yield efficiency $\left(\mathrm{kg} / \mathrm{cm}^{2} \mathrm{TCSA}\right)$ \\
\hline $30-40$ & $34.3 \mathrm{~d}$ & $4.7 \mathrm{c}$ & $6.6 \mathrm{c}$ & $196.3 \mathrm{a}$ & $0.9 \mathrm{c}$ \\
$50-65$ & $55.7 \mathrm{c}$ & $7.5 \mathrm{c}$ & $8.5 \mathrm{c}$ & $151.8 \mathrm{ab}$ & $1.1 \mathrm{c}$ \\
$75-85$ & $83.7 \mathrm{~b}$ & $11.3 \mathrm{~b}$ & $12.0 \mathrm{~b}$ & $143.7 \mathrm{~b}$ & $1.6 \mathrm{~b}$ \\
$90-100$ & $95.0 \mathrm{~b}$ & $12.5 \mathrm{~b}$ & $14.0 \mathrm{~b}$ & $147.7 \mathrm{ab}$ & $1.8 \mathrm{ab}$ \\
$125-135$ & $130.0 \mathrm{a}$ & $16.0 \mathrm{a}$ & $17.0 \mathrm{a}$ & $130.8 \mathrm{~b}$ & $2.1 \mathrm{a}$ \\
Significance $^{\mathrm{z}}$ & $* * *$ & $* * *$ & $* * *$ & $*$ & $* * *$ \\
\hline
\end{tabular}

${ }^{2}$ Significance was established with proc GLM in SAS, type III sums of squares. Means comparisons were established with post hoc Tukey test. Means in a column followed by the same letter are not statistically different at $P<0.05$.

Ns, ${ }^{*}, * *, * * *$ Nonsignificant or significant at $P \leq 0.05,0.01$, or 0.001 , respectively.

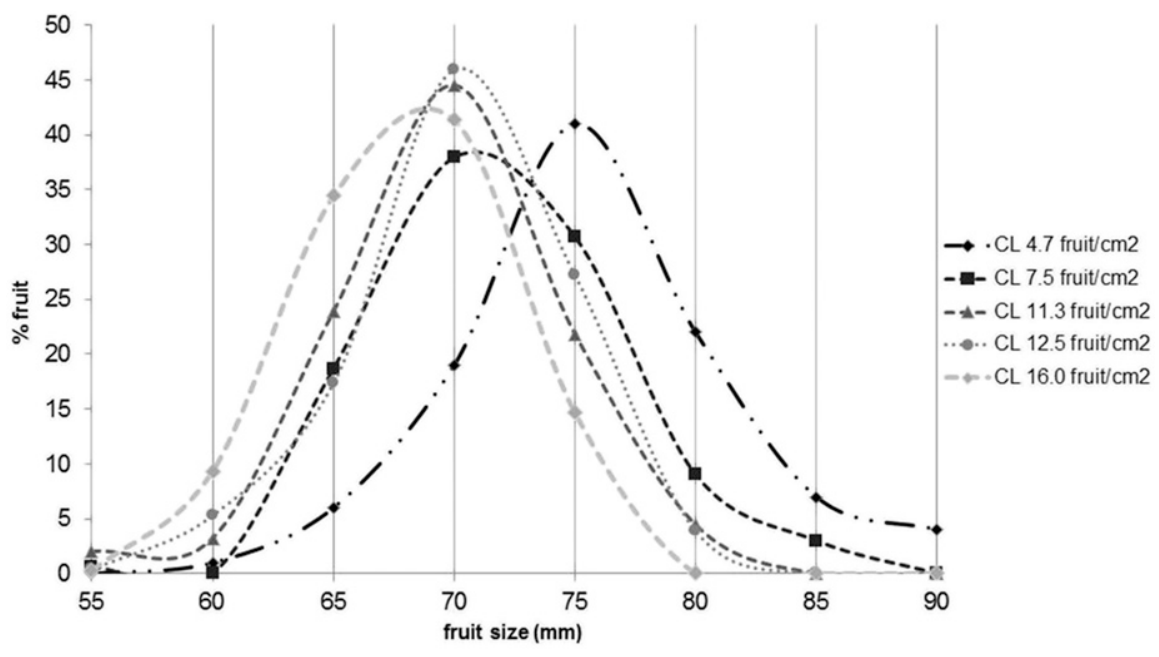

Fig. 1. The distribution (\% fruit) of fruit size ( $\mathrm{mm}$ ) at harvest according to crop load (CL) in 'Honeycrisp' apple fruit grown in the northwestern United States.

powder in a high throughput homogenizer (VWR, Radnor, PA). For Ca, K, and Mg analysis, $200 \mathrm{mg}$ of ground sample was oven digested with $6 \mathrm{~mL}$ nitric acid. Then samples were diluted 100fold and analyzed using an Agilent $4200 \mathrm{MP}-$ AES (Santa Clara, CA). Calcium, Mg, and $\mathrm{K}$ standards were created to bracket the estimated concentration of each element in the ground fruit tissue. For N, $500 \mathrm{mg}$ of dried sample was analyzed using an elemental analyzer (Brookside Laboratories, $\mathrm{OH}$ ).

Return bloom and fruit set. In April of the following year, the total number of flower clusters per tree were counted at $20 \%$ full bloom and the TCSA determined again (on the base of a new measurements of trunks at $15 \mathrm{~cm}$ above the grafting point) to calculate the blossom cluster density according to Embree et al. (2007) as cluster number/TCSA. The height of each tree was also measured to determine the homogeneity of height and TCSA distribution across replicates. Fruit set was estimated $43 \mathrm{~d}$ after bloom by counting the total number of fruitlets per tree.

Statistical analyses. Yield, quality, maturity data at harvest and 6 months storage and return bloom were analyzed with proc GLM in SAS (SAS Inc., Cary, NC). Fruit from T0 and T1 were analyzed separately. Both crop load (4.7, 7.5, $11.3,12.5$, and 16.0 fruit/TCSA $\mathrm{cm}^{2}$ ) and $I_{\mathrm{AD}}$ classes $(<0.60,0.60-0.99$, and $>1.00)$ were analyzed separately using a one-way analysis of variance (ANOVA). The $I_{\mathrm{AD}}$ classes determined at 1 month were retained for the 6 month analysis; no additional categorization was performed. The model was considered significant at $P<0.05$ with the type III sums of squares test. Posthoc means separation was performed with Tukey's honest significant difference (HSD). For binary data from postharvest disorder incidence or fruit shape and patterning (asymmetry, color striping/mottling) proc logistic was performed in SAS to determine if distributions of incidence were different $(P<$ 0.05) (Supplemental Table 1). Linear or logarithmic regression lines were drawn using Microsoft Excel 2010 software. The $R^{2}$ values were calculated using Microsoft Excel 2010 software. The effect of crop load on plant nutrient composition was analyzed using a one-way ANOVA in OriginPro 9.1 and post hoc means separation was performed with Tukey's HSD.

\section{Results and Discussion}

Effects of crop load on yield and fruit size. The trees with the lowest crop load had an average of 4.7 fruit $/ \mathrm{cm}^{2}$ TCSA and the highest targeted crop load had 16.0 fruit $/ \mathrm{cm}^{2}$ TCSA (Table 1). Actual average numbers of fruits per crop load class were statistically distinct with the exception of crop loads 11.3 and 12.5 fruit $/ \mathrm{cm}^{2}$. As expected, the 16.0 fruit $/ \mathrm{cm}^{2}$ crop load recorded the heaviest production $(17 \mathrm{~kg} /$ tree $)$. Trees with crop loads of 11.3 and 12.5 fruit $/ \mathrm{cm}^{2}$ had similar and significantly higher yield than the two lowest crop loads, producing 12 and $14 \mathrm{~kg} /$ tree, respectively, compared with 6.6 and $8.5 \mathrm{~kg} /$ tree for trees with 4.7 and 7.5 fruit $/ \mathrm{cm}^{2}$, respectively (Table 1). Average individual fruit weight for the lowest crop load (4.7 fruit/ $\mathrm{cm}^{2}$ ) was $196 \mathrm{~g}$. This was, on average, $65 \mathrm{~g}$ greater than fruit harvested from the trees with the heaviest crop load $\left(16.0\right.$ fruit $\left./ \mathrm{cm}^{2}\right)$ $(P<0.05)$. Fruit weight was not significantly different among the intermediate crop loads. Yield efficiency (fruit weight per square centimeter of TCSA) was the highest $\left(2.1 \mathrm{~kg} \cdot \mathrm{cm}^{-2}\right)$ in trees with a high crop load while trees with the lowest crop load had a mean yield efficiency of $0.9 \mathrm{~kg} \cdot \mathrm{cm}^{-2}$ (Table 1 ).

Crop load significantly affected the size distribution of the fruit harvested from trees of each crop load. The total percentage of fruit that was less than $70 \mathrm{~mm}$ increased as crop load increased. Six percent of fruit was less than $70 \mathrm{~mm}$ for trees with the lowest crop load and $\approx 43 \%$ of fruit was less than $70 \mathrm{~mm}$ for trees with the highest crop load (Fig. 1). Trees with crop loads of $7.5 \mathrm{fruit} / \mathrm{cm}^{2}$ had the most optimum size distribution with no oversized fruit that were observed with low crop loads and fewer undersized fruit that were observed in higher proportions at higher crop loads.

As expected, fruit size was affected by crop load. Trees with crop loads of $7.5 \mathrm{fruit} / \mathrm{cm}^{2}$ had significantly smaller fruit (152 $\mathrm{g}$ equal to 125 fruit/box) relative to 4.7 fruit $/ \mathrm{cm}^{2}(196 \mathrm{~g}$ equal to 100 fruit/box). Fruit size of $200-250 \mathrm{~g}$ is considered optimal for the market (Robinson and Watkins, 2003). Crop loads exceeding 10 fruit $/ \mathrm{cm}^{2}$ strongly reduced fruit size (Robinson and Watkins, 2003). In our experiment, the highest crop load $\left(16.0\right.$ fruit $\left./ \mathrm{cm}^{2}\right)$ produced very small fruit equal to $131 \mathrm{~g}$ (corresponding to 150 /box), which can result in a large reduction in marketable fruit. Data from the present study suggests that crop loads of 5 to 7 fruit $/ \mathrm{cm}^{2}$ are needed to achieve an acceptable and marketable size for 'Honeycrisp'. This is similar to crop load recommendations made by Robinson and Watkins (2003) in a study carried out in New York State. In our trial, overall yield ranged from $29 \mathrm{t} \cdot \mathrm{ha}^{-1}$ (4.7 fruit $\left./ \mathrm{cm}^{2}\right)$ up to $76 \mathrm{t} \cdot \mathrm{ha}^{-1}$ (16 fruit $\left./ \mathrm{cm}^{2}\right)$. The highest crop load resulted in a dramatic reduction in fruit size, so for this reason, it is not recommended to exceed 12.5 fruit $/ \mathrm{cm}^{2}$.

Effects of crop load on fruit quality. Data were initially analyzed to determine treatment effects of postharvest storage duration, crop load, and $I_{\mathrm{AD}}$ (Supplemental Table 2). 


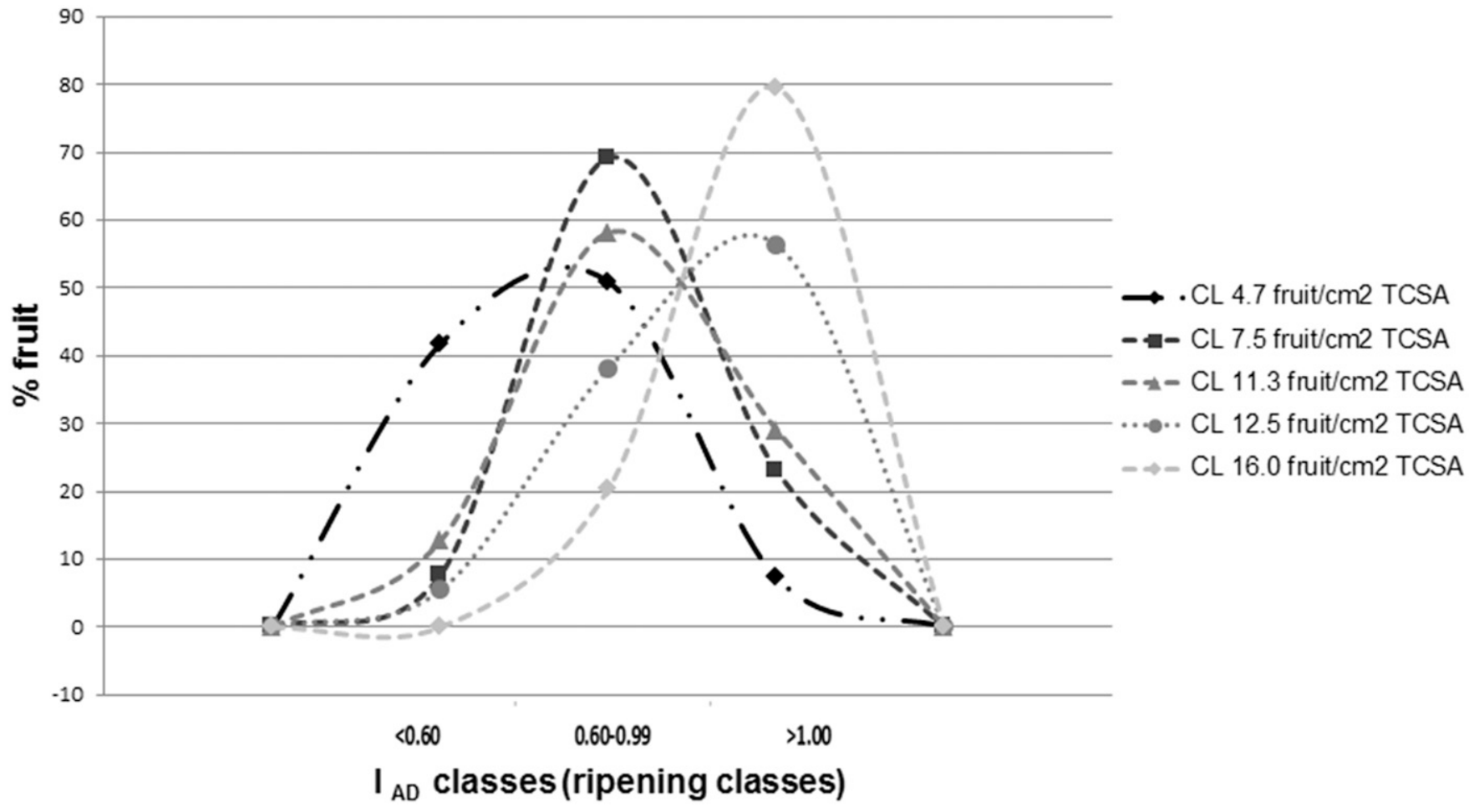

Fig. 2. The distribution (\% fruit) of $I_{\mathrm{AD}}$ measurements shortly after harvest $\left(1\right.$ month at $\left.1{ }^{\circ} \mathrm{C}\right)$ according to crop load (CL) for 'Honeycrisp' apple fruit grown in the northwestern United States.

Crop load affected fruit maturity (Fig. 2). The proportion of fruit in three established $I_{\mathrm{AD}}$ $(<0.60,0.60-0.99$, and $>1.0)$ categories were significantly different among the different crop loads (Fig. 2). Trees with 16.0 fruit/ $\mathrm{cm}^{2}$ produced the least ripe fruit with $79.6 \%$ of them belonging to the $I_{\mathrm{AD}}>1.0$ class. On the contrary, trees with 4.7 fruit $/ \mathrm{cm}^{2}$ showed an $I_{\mathrm{AD}}$ fruit distribution where nearly $41.8 \%$ fruit belonged to the lowest class $\left(I_{\mathrm{AD}}<0.60\right.$, more ripe fruit). The intermediate crop load levels showed an intermediate maturity behavior (Fig. 2). In trees with 12.5 fruit $/ \mathrm{cm}^{2}$, only $56.4 \%$ of the fruit belonged to the least ripe class. In trees with 11.5 fruit $/ \mathrm{cm}^{2}$, the percentage belonging to the least ripe class decreased to $29.1 \%$. In the lowest crop load treatment $\left(4.7\right.$ fruit $\left./ \mathrm{cm}^{2}\right)$, only $7.3 \%$ of fruit could be classified in this category $\left(I_{\mathrm{AD}}>\right.$ 1.00 , less ripe fruit, Fig. 2). In peaches, Ziosi et al. (2008) reported the same decrease in $I_{\mathrm{AD}}$ as fruit ripening progressed. Our data also agree with Palmer et al. (1997) that described earlier maturation of apples on trees with low crop load compared with heavier crop loads. Also Faragher and Brohier (1984) reported ethylene production and anthocyanin synthesis $10 \mathrm{~d}$ later for the apple variety 'Jonathan' on trees with high crop loads relative to low crop loads. In the present experiment, apples from trees with low and medium crop loads (4.7 and $7.5 \mathrm{fruit} / \mathrm{cm}^{2}$ ) had fruit that belonged to the intermediate ripening class $0.60<I_{\mathrm{AD}}<0$.

There were significant differences among the three $I_{\mathrm{AD}}$ categories both at harvest and after storage. In general, a decrease in $I_{\mathrm{AD}}$ over the 5 months was reported for each crop load level [0.40 as average $I_{\mathrm{AD}}$ drop (T0-T1) between the five crop loads] with no statistical difference among crop loads (data not shown). The decrease in $I_{\mathrm{AD}}$ during storage was greatest in the $I_{\mathrm{AD}}>1.00$ class (Fig. 4B), which indicates that these fruit were comparatively less ripe at harvest relative to other $\mathrm{I}_{\mathrm{AD}}$ classes and became more ripe during storage. Also DeLong et al. (2014) demonstrated that $I_{\mathrm{AD}}$ readings are negatively correlated with the harvest date: earlier harvest times had higher $I_{\mathrm{AD}}$ values but fruit also showed a broad distribution of $I_{\mathrm{AD}}$ readings at each harvest date indicating highly variable levels of fruit ripeness within the canopy. After storage, fruit weight decreased by the same amount for all crop loads, but in general the drop in weight ranged from 3.7 to $5.8 \mathrm{~g}$ in 5 months of storage (Table 3 ). Similar results were reported by Wright et al. (2006). However, fruit classified in the different $I_{\mathrm{AD}}$ classes presented no differences in weight (Tables 2 and 3), confirming the homogeneity of fruit collected for the size range of 75-84 mm.

A month after harvest, the visual assessment of red overcolor peel area percentage indicated that lower crop loads ( 4.7 fruit $/ \mathrm{cm}^{2}$ ) resulted in a greater percentage of red color in the peel $(71 \%)$ while the highest crop load (16 fruit $/ \mathrm{cm}^{2}$ ) showed only $40 \%$ of the redblushed surface (Table 2). Fruit analyzed after 6 months from harvest showed the same trends in color with $70 \%$ and $50 \%$ redblushed surface, for the lowest and the highest crop load category, respectively (Table 3 ). Similar results were reported by Wright et al. (2006) in 'Honeycrisp' with crop loads ranging from 3 to 9 fruit $/ \mathrm{cm}^{2}$ TCSA. Color development (lightness, hue, and chroma) was influenced by crop load at harvest (T0) and after storage (T1). The $h^{\circ}$ on the overcolor increased as crop load increased (Table 2 ) and the trend was maintained during storage (Table 3). Background color was more yellow for fruit from trees with the lowest crop loads where the $h^{\circ}$ for the two lowest crop loads ( 4.7 and 7.5 fruit $/ \mathrm{cm}^{2}$ ) were 102.3 and 101.5, respectively. For fruit from trees with the highest crop load, the $h^{\circ}$ was 109.1 and was significantly greater than the fruit from trees with the two lowest crop loads (Table 2). These data were similar to Robinson and Watkins (2003) that described reduced color in fruit from trees with heavy crop loads. The lowest $I_{\mathrm{AD}}$ class showed the highest red overcolor percentage together with the highest chroma and lowest $h^{\circ}$ of the overcolor (indicating a more saturated red color than the one reported for the $I_{\mathrm{AD}}>1.00$ class (Tables 2 and 3 ). Therefore, ripeness, as indicated by the DA-meter, corresponded to color development. The background color of the highest $I_{\mathrm{AD}}$ class was also more oriented toward the green hue than the yellow. In contrast, fruit from the lowest crop load was oriented more toward the yellow hue than the green hue (Tables 2 and 3 ). The differences in fruit maturity observed between the two classes here were similar to results reported in Palmer et al. (1997).

Fruit from trees with lower crop loads (4.7 to $\left.7.5 \mathrm{fruit} / \mathrm{cm}^{2}\right)$ were firmer and had higher SSC (Figs. 3A and 4A). Those two crop load categories were significantly different at harvest, but after storage, there were no significant differences in firmness and SSC. Alcobendas 
Table 2. Effect of crop load on measures of fruit quality and maturity shortly after harvest ( 1 month of storage at $\left.1{ }^{\circ} \mathrm{C}\right)$, and differences in measures of fruit quality and maturity according the $I_{\mathrm{AD}}$ classification for 'Honeycrisp' apple fruit grown in the northwestern United States.

\begin{tabular}{|c|c|c|c|c|c|c|c|c|c|c|c|}
\hline \multirow[b]{2}{*}{$\begin{array}{l}\text { Crop load (no. } \\
\text { fruit } / \mathrm{cm}^{2} \text { TCSA) }\end{array}$} & \multirow[b]{2}{*}{$\begin{array}{c}I_{\mathrm{AD}} \\
\text { range }\end{array}$} & \multirow[b]{2}{*}{ Wt (g) } & \multirow[b]{2}{*}{$I_{\mathrm{AD}}(\mathrm{T} 0)$} & \multicolumn{5}{|c|}{ Color parameters } & \multirow[b]{2}{*}{$\begin{array}{l}\text { Starch } \\
(1-6)\end{array}$} & \multirow[b]{2}{*}{$\begin{array}{c}\text { IEC } \\
(\mu \mathrm{mol})^{\mathrm{z}}\end{array}$} & \multirow[b]{2}{*}{$\mathrm{pH}^{\mathrm{y}}$} \\
\hline & & & & $\begin{array}{l}\text { Red-blushed surface } \\
\text { (overcolor) }(\%)\end{array}$ & $\begin{array}{l}\text { Overcolor } \\
\left(h^{\circ}\right)\end{array}$ & $\begin{array}{l}\text { Overcolor } \\
\text { (chroma) }\end{array}$ & $\begin{array}{c}\text { Background } \\
\left(h^{\circ}\right)\end{array}$ & $\begin{array}{l}\text { Background } \\
\text { (chroma) }\end{array}$ & & & \\
\hline 4.7 & & $191.7 \mathrm{a}$ & $0.65 \mathrm{c}$ & $71 \mathrm{a}$ & $33.5 \mathrm{c}$ & $43.5 \mathrm{a}$ & $102.3 \mathrm{~b}$ & $45.9 \mathrm{a}$ & $4.0-$ & $0.5 \mathrm{~b}$ & $3.34-$ \\
\hline 12.5 & & $174.4 \mathrm{bc}$ & $0.96 \mathrm{ab}$ & $54 \mathrm{~b}$ & $55.9 \mathrm{~b}$ & $35.0 \mathrm{c}$ & $107.8 \mathrm{a}$ & $44.7 \mathrm{a}$ & $4.6-$ & $0.2 \mathrm{~b}$ & $3.32-$ \\
\hline 16.0 & & $168.5 \mathrm{c}$ & $1.10 \mathrm{a}$ & $40 \mathrm{c}$ & $66.1 \mathrm{a}$ & $33.7 \mathrm{c}$ & $109.1 \mathrm{a}$ & $45.4 \mathrm{a}$ & $4.2-$ & $0.0 \mathrm{~b}$ & $3.35-$ \\
\hline Significance ${ }^{\mathrm{x}, \mathrm{w}}$ & & $* * *$ & $* * *$ & $* * *$ & $* * *$ & $* * *$ & $* * *$ & $* * *$ & NS & $* * *$ & NS \\
\hline & $>1.00$ & 177.9 & $1.1 \mathrm{a}$ & $44.9 \mathrm{c}$ & $63.6 \mathrm{a}$ & $33.7 \mathrm{c}$ & $108.2 \mathrm{a}$ & $45.6 \mathrm{a}$ & $3.8 \mathrm{c}$ & $0.2 \mathrm{c}$ & $3.31 \mathrm{c}$ \\
\hline Significance $^{\mathrm{x}}$ & & * & $* * *$ & $* * *$ & $* * *$ & $* * *$ & $* * *$ & $* * *$ & $* * *$ & $*$ & $* * *$ \\
\hline
\end{tabular}

$h^{\circ}=$ Hue angle; TCSA $=$ trunk cross-sectional area.

${ }^{\mathrm{z}} \mathrm{IEC}$, internal ethylene concentration.

${ }^{\mathrm{y}} \mathrm{pH}$ was analyzed independently due to differing numbers of replication.

${ }^{x}$ Significance was established with proc GLM in SAS, type III sums of squares. Means comparisons were established with post hoc Tukey test.

Means in a column followed by the same letter are not statistically different at $P<0.05$.

ss,*, **, ${ }^{* * *}$ Nonsignificant or significant at $P \leq 0.05,0.01$, or 0.001 , respectively.

Table 3. Effect of crop load on measures of fruit quality and maturity 6 months after harvest $\left(6\right.$ months of storage at $\left.1{ }^{\circ} \mathrm{C}\right)$, and differences in measures of fruit quality and maturity according the $I_{\mathrm{AD}}$ classification for 'Honeycrisp' apple fruit grown in the northwest United States.

\begin{tabular}{|c|c|c|c|c|c|c|c|c|c|c|c|}
\hline \multirow[b]{2}{*}{$\begin{array}{l}\text { Crop load (no. } \\
\text { fruit } / \mathrm{cm}^{2} \text { TCSA) }\end{array}$} & \multirow[b]{2}{*}{$I_{\mathrm{AD}}$ range } & \multirow[b]{2}{*}{$\begin{array}{c}\text { Wt } \\
\text { drop }(g)^{z}\end{array}$} & \multirow[b]{2}{*}{$I_{\mathrm{AD}}(\mathrm{T} 1)$} & \multicolumn{5}{|c|}{ Color parameters } & \multirow[b]{2}{*}{$\begin{array}{l}\text { Starch } \\
(1-6)\end{array}$} & \multirow[b]{2}{*}{$\begin{array}{c}\text { IEC } \\
(\mu \mathrm{mol})^{y}\end{array}$} & \multirow[b]{2}{*}{$\mathrm{pH}^{x}$} \\
\hline & & & & $\begin{array}{l}\text { Red-blushed surface } \\
\text { (overcolor) }(\%)\end{array}$ & $\begin{array}{l}\text { Overcolor } \\
\left(h^{\circ}\right)\end{array}$ & $\begin{array}{l}\text { Overcolor } \\
\text { (chroma) }\end{array}$ & $\begin{array}{c}\text { Background } \\
\left(h^{\circ}\right)\end{array}$ & $\begin{array}{l}\text { Background } \\
\text { (chroma) }\end{array}$ & & & \\
\hline 4.7 & & $5.8 \mathrm{a}$ & $0.26 \mathrm{c}$ & $70 \mathrm{a}$ & $34.9 \mathrm{c}$ & $44.0 \mathrm{a}$ & $92.4 \mathrm{c}$ & $45.6 \mathrm{bc}$ & 6.0 & $4.3 \mathrm{ab}$ & $3.36 \mathrm{a}$ \\
\hline 12.5 & & $3.7 \mathrm{~b}$ & $0.63 \mathrm{a}$ & $45 \mathrm{~b}$ & $59.3 \mathrm{ab}$ & $37.0 \mathrm{bc}$ & $100.8 \mathrm{ab}$ & $45.8 \mathrm{bc}$ & 6.0 & $1.4 \mathrm{c}$ & $3.24 \mathrm{~b}$ \\
\hline 16.0 & & $5.5 \mathrm{a}$ & $0.64 \mathrm{a}$ & $50 \mathrm{~b}$ & $65.6 \mathrm{ab}$ & $40.0 \mathrm{a}$ & $100.3 \mathrm{ab}$ & $49.9 \mathrm{a}$ & 6.0 & $3.6 \mathrm{ab}$ & $3.31 \mathrm{ab}$ \\
\hline Significance $^{\mathrm{w}}$ & & $* * *$ & $* * *$ & $* * *$ & $* * *$ & $* * *$ & ** & $* * *$ & NS & $* * *$ & NS \\
\hline & $>1.00$ & 4.7 & $0.67 \mathrm{a}$ & $44 \mathrm{c}$ & $65.3 \mathrm{c}$ & $37.8 \mathrm{c}$ & $101.7 \mathrm{a}$ & $48.9 \mathrm{a}$ & 6.0 & 2.2 & $3.26 \mathrm{c}$ \\
\hline Significance $^{\mathrm{w}}$ & & NS & $* * *$ & $* * *$ & $* * *$ & ** & $* * *$ & $* * *$ & NS & NS & $* * *$ \\
\hline
\end{tabular}

$h^{\circ}=$ Hue angle; TCSA $=$ trunk cross-sectional area.

${ }^{\text {z}}$ From harvest to 6-month postharvest storage.

'IEC, internal ethylene concentration.

${ }^{\mathrm{x}} \mathrm{pH}$ was analyzed independently due to differing numbers of replication.

wSignificance was established with proc GLM in SAS, type III sums of squares. Means comparisons were established with post hoc Tukey test.

Means in a column followed by the same letter are not statistically different at $P<0.05$.

Ns, ${ }^{*}, * * * * *$ Nonsignificant or significant at $P \leq 0.05,0.01$, or 0.001 , respectively.

et al. (2012) reported firmer peaches from trees with low crop loads. Fruit did not lose firmness during storage (Supplemental Table 3) following a predictable trait of 'Honeycrisp' to maintain firmness during storage (Mann et al., 2005; Wargo and Watkins, 2004). At harvest, fruit from the lowest $I_{\mathrm{AD}}$ class was more firm than the other two $I_{\mathrm{AD}}$ classes (Fig. 3B). After storage, there was no significant difference in fruit firmness among the three $I_{\mathrm{AD}}$ classes (Fig. 4B). Fruit from lower crop loads have been previously found to have more cells in the cortical region and is influenced by the time of thinning and is cultivar dependent (Bergh, 1990). Link (2000) pointed out other factors affecting the fruit firmness such as number and size of cells, intercellular space volume, and dry matter. In trees with high crop loads, fruit competes for a limited carbohydrate supply. Insufficient carbohydrate reserves limit cell wall development, and consequently affect fruit firmness. Trees with low crop loads produce fruit with higher dry matter and firmness (Link, 2000).

Soluble solute content decreased as crop loads increased (Figs. 3A and 4A). After 1 month of storage, SSC in the lightest crop level was more than $2{ }^{\circ}$ Brix greater compared with the heaviest crop load (Fig. 3A). After 6 months of storage, the difference between those two crop loads decreased to $1.1{ }^{\circ}$ Brix (Fig. 4A). At T0, fruit that belonged to the $I_{\mathrm{AD}}<0.60$ class contained more soluble solids than the other classes (Fig. 3B). SSC at T1 was not different between the two lowest $I_{\mathrm{AD}}$ classes, while fruit with $I_{\mathrm{AD}}>1.00$ class was $1{ }^{\circ}$ Brix lower than fruit belonging to the 0.60 $0.99 I_{\mathrm{AD}}$ class (Fig. 4B). No differences among crop loads were observed in visual starch assessment at $\mathrm{T} 0$ and $\mathrm{T} 1$ (Tables 2 and $3)$. While among $I_{\mathrm{AD}}$ classes, SI showed higher value in the lowest $I_{\mathrm{AD}}$ class (4.8) (indicating more ripe fruit belonging to that group) in comparison with the $I_{\mathrm{AD}}>1.00$ class where the fruit were more unripe (3.8) (Table 3). After 6 months of storage, the starch was completely hydrolyzed reporting a value of six for all crop loads levels (Table 3).

Dry matter was significantly higher in fruit from lower crop loads with a difference in dry matter of $2.8 \%$ between fruit from the lowest and the highest crop loads (Fig. 3A). Dry matter percentage measured at 6 months after storage showed a $1.9 \%$ difference between the two extreme crop loads and it was significantly higher in fruit from lower crop loads with clear differences for fruit from trees with crop loads either less than or greater than 11.3 fruit $/ \mathrm{cm}^{2}$ (Fig. 4A). Dry matter is an important component of fruit quality contributing to improve the consumer acceptability of the fruit (Palmer et al., 2010). In our trial, the values ranged from 126 to $154 \mathrm{~g} \cdot \mathrm{kg}^{-1}$ [transforming dry matter percentage to dry matter concentration (DMC)] with a clear effect of the crop load level. Palmer et al. 2010 postulated that fruit with high DMC is more preferred by the consumer. Other crops like avocado, mango, and kiwifruit are using DMC to assess the quality (Gamble et al., 2010; Harker et al., 2009; Saranwong et al., 2004). According to Palmer and colleagues (2010), Royal 'Gala' apples stored for $10-12$ weeks at $0.5{ }^{\circ} \mathrm{C}$ showed significative differences in fruit quality parameters like DMC, SSC, and TA. In that study, fruit were classified according to the DMC in high $\left(157 \mathrm{~g} \mathrm{~kg}^{-1}\right)$, moderate $\left(143 \mathrm{~g} \mathrm{~kg}^{-1}\right)$, and low (132 $\mathrm{g} \cdot \mathrm{kg}^{-1}$ ) category (Palmer et al., 2010). 
A)

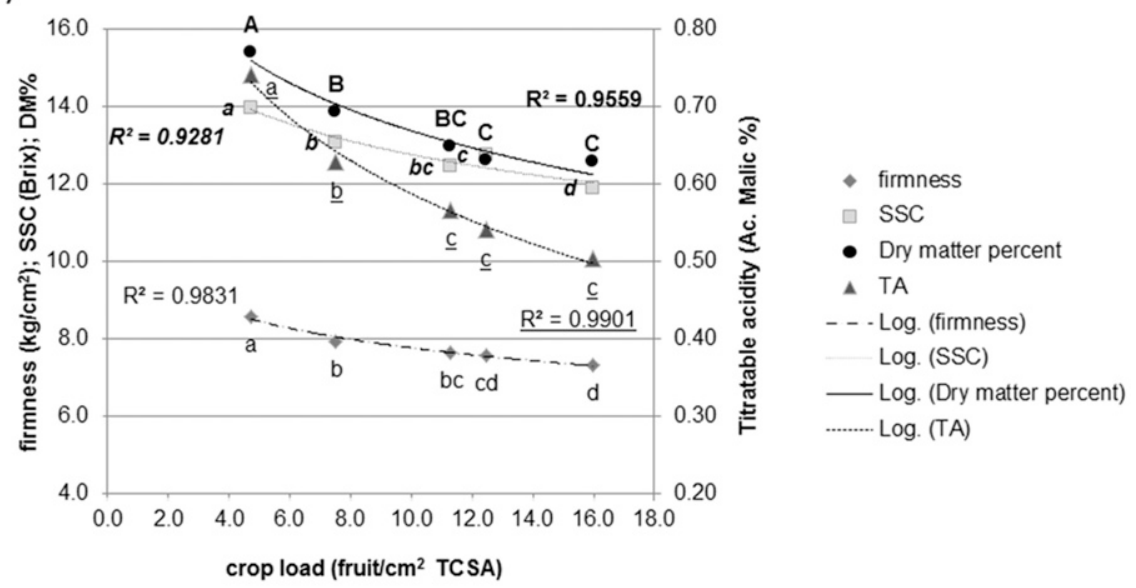

B)

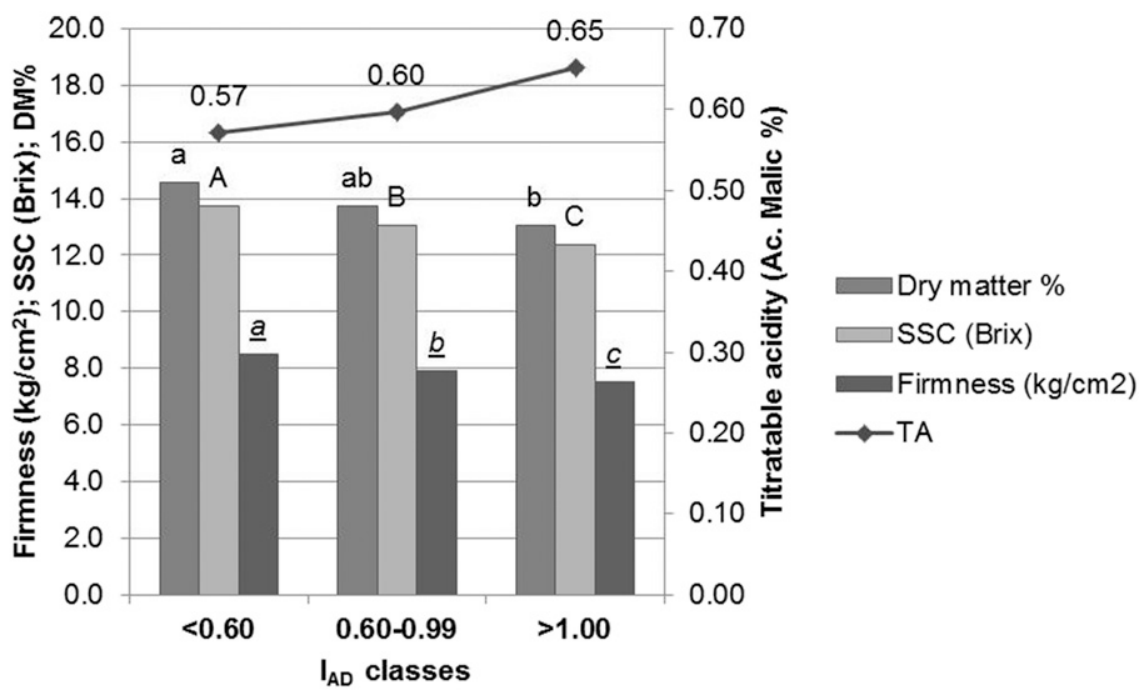

Fig. 3. Effect of crop load on (A) fruit quality parameters and maturity (firmness, soluble solid concentration (SSC), dry matter percentage (DM\%), titratable acidity (TA) shortly after harvest ( 1 month of storage at $\left.1{ }^{\circ} \mathrm{C}\right)$, and $(\mathbf{B})$ differences in measures of fruit quality and maturity according to the $I_{\mathrm{AD}}$ classification for 'Honeycrisp' apple fruit grown in the northwest United States. Means comparisons were established with post hoc Tukey test. Means followed by the same letter and font are not statistically different at $P<0.05$.

Here, DMC was over $150 \mathrm{~g} \mathrm{~kg}^{-1}$ for fruit from trees with low crop loads (Figs. 3A and $4 \mathrm{~A}$ ) and can be classified as high/ moderate DMC category for Royal 'Gala' (Palmer et al., 2010). There is not a known classification of optimum DMC for 'Honeycrisp'. A negative correlation between dry matter percentage and crop load levels was found both at T0 and T1 (Figs. 3A and 4A) resulting in logarithmic trends with $R^{2}$ high values $\left(R^{2}=0.9559 \mathrm{~T} 0\right.$ and $\left.R^{2}=0.9384 \mathrm{~T} 1\right)$. Dry matter percentage showed significant differences between the three $I_{\mathrm{AD}}$ classes of fruit 1 month after harvest (Fig. 3B), with the lowest $I_{\mathrm{AD}}$ class having fruit with higher dry matter $(1.5 \%$ more than the highest class $\left.I_{\mathrm{AD}}>1\right)$. After 6 months of storage, dry matter content was not significantly different among $I_{\mathrm{AD}}$ classes (Fig. 4B).

Crop load had no effect on fruit $\mathrm{pH}$ at $\mathrm{T} 0$, but TA was highest in fruit from trees with lower crop loads, while the TA in fruit from
$I_{\mathrm{AD}}$ classes, TA was not significantly different (Fig. 4B).

At T0, IEC after 1 month in storage was low (Table 2) with a significant difference between 7.5 fruit $/ \mathrm{cm}^{2}$ treatment $(1.1 \mu \mathrm{mol}$ IEC) and the other four crop loads (ranging from 0.0 to $0.5 \mu \mathrm{mol}$ IEC). No significant differences were observed between the other crop levels. At T0, ethylene concentration was the greatest in the lowest $I_{\mathrm{AD}}$ class $(0.6 \mu \mathrm{mol})$, indicating more ripe fruit belonging to that group (Table 2). After 6 months of storage, IEC data were not significantly different among crop loads with IEC ranging from 1.2 to $4.3 \mu \mathrm{mol}$ (Table 3 ). IEC was lower as $I_{\mathrm{AD}}$ increased after being stored for 6 months (Table 3).

Robinson and Watkins (2003) also observed a weak relationship between crop load and IEC in 'Honeycrisp'. IEC had an inverse relationship with $I_{\mathrm{AD}}$, although all measures of IEC were above what is considered to be the climacteric threshold in 'Honeycrisp' (Watkins et al., 2005). IEC is highly variable in 'Honeycrisp' fruit and was neither associated with fruit harvest date nor with disorders related to increased maturity in 'Honeycrisp' (Tong et al., 2003; Wargo and Watkins, 2004; Watkins et al., 2005).

Fruit nutritional balance. $\mathrm{Ca}$ concentration was the lowest and $\mathrm{K}, \mathrm{Mg}$, and $\mathrm{N}$ concentration was the greatest for fruit harvested from trees with low crop loads (Table 4). Once crop loads exceeded $11 \mathrm{fruit} / \mathrm{cm}^{2}$, there was no difference in fruit mineral concentration among crop load treatments. Fruit $\mathrm{Ca}$ generally increased up to 12.5 fruit $/ \mathrm{cm}^{2}$ while $\mathrm{K}, \mathrm{Mg}$, and $\mathrm{N}$ concentrations showed a decreasing trend as crop load increased (Table 4). All three traditional elemental ratios $[(\mathrm{K}+\mathrm{Mg}+\mathrm{N}): \mathrm{Ca}, \mathrm{N}: \mathrm{Ca}$, and $(\mathrm{K}+\mathrm{Mg}): \mathrm{Ca}]$ used as indicators of susceptibility to bitter pit showed similar trends among crop loads (Fig. 5). Particularly at low crop loads the ratios were greater, indicating possible susceptibility to bitter pit (Ferguson and Watkins, 1992). Bitter pit is known to be associated with either low $\mathrm{Ca}$ or high $\mathrm{N}, \mathrm{K}$, or $\mathrm{Mg}$ or any combination of those three factors. Surprisingly, although 'Honeycrisp' is known to be sensitive to postharvest disorders such as bitter pit, minimal disorders were observed that would provide information on the relationship between crop load and important abiotic disorders such as bitter pit and soft scald (Supplemental Table 1). The extreme low incidence of postharvest disorders may be attributed to the low vigor of the orchard and limited vegetative growth. Early production likely limited growth of the orchard and inhibited canopy development and tree vigor. This situation was also reported by Robinson and Watkins (2003) who observed that early cropping of 'Honeycrisp', particularly when combined with dwarfing rootstocks like M9-Nic29, reduces tree growth.

Return bloom and fruit set. The difference in return bloom was significant $(P=$ 0.0024 and $P=0.0016$ for the number of cluster/tree and flower blossom density, respectively) among the crop loads. The highest 
A)

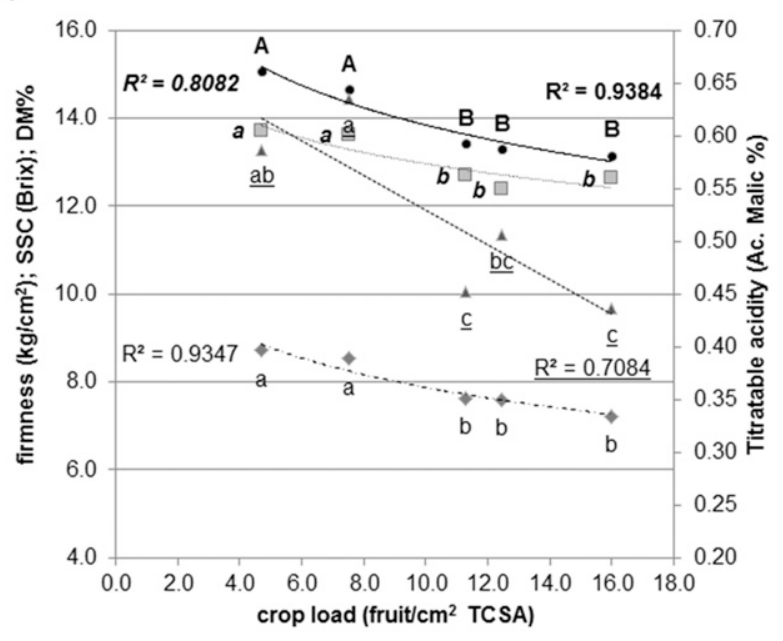

B)

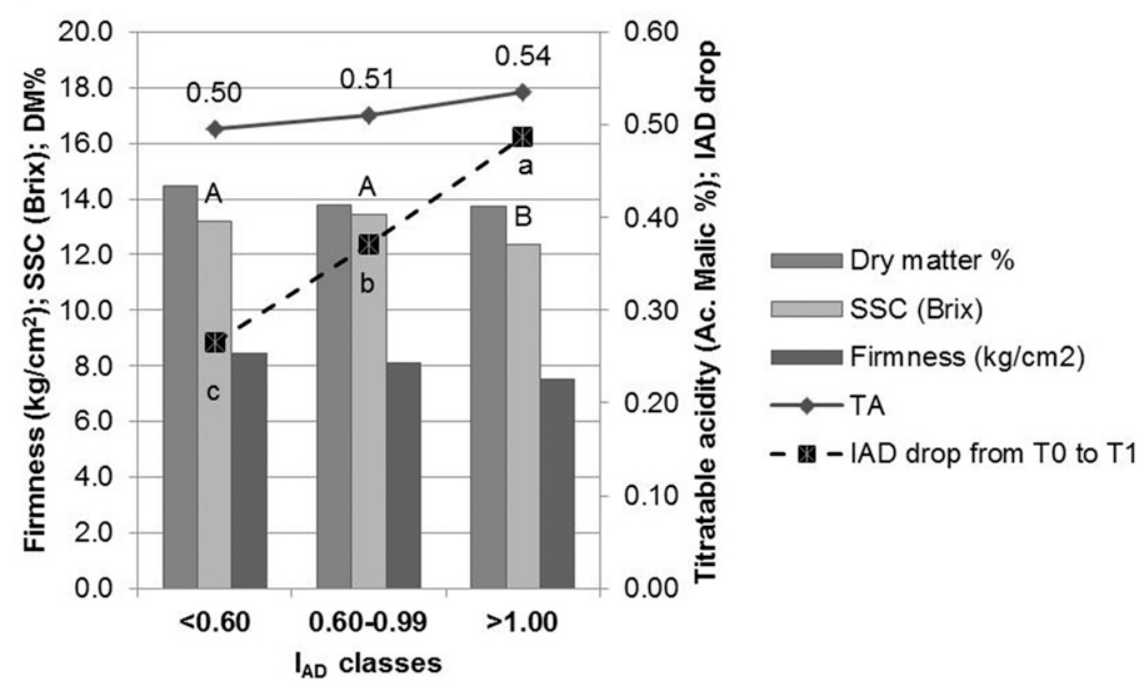

Fig. 4. Effect of crop load on (A) fruit quality parameters and maturity (firmness, soluble solid concentration (SSC), dry matter percentage (DM\%), titratable acidity (TA) after 6 months from harvest ( 6 months of storage at $1{ }^{\circ} \mathrm{C}$ ) and (B) differences in measures of fruit quality and maturity according the $I_{\mathrm{AD}}$ classification for 'Honeycrisp' apple fruit grown in the northwest United States. Means comparisons were established with post hoc Tukey test. Means followed by the same letter and font are not statistically different at $P<0.05$.

Table 4. Calcium $(\mathrm{Ca})$, potassium $(\mathrm{K})$, magnesium $(\mathrm{Mg})$, and nitrogen $(\mathrm{N})$ concentration $(\% \mathrm{w} / \mathrm{w})$ of 'Honeycrisp' apple tissue from trees thinned to crop loads of 4.7, 7.5, 11.3, 12.5, and $16 \mathrm{fruit} / \mathrm{cm}^{2}$.

\begin{tabular}{|c|c|c|c|c|}
\hline & $\mathrm{Ca}$ & $\mathrm{K}$ & $\mathrm{Mg}$ & $\mathrm{N}$ \\
\hline Crop Load(fruit $/ \mathrm{cm}^{2}$ ) & \multicolumn{4}{|c|}{$\% \mathrm{w} / \mathrm{w}$} \\
\hline 4.7 & $0.0271 \mathrm{~b}$ & $1.016 \mathrm{a}$ & $0.041 \mathrm{a}$ & $0.237 \mathrm{a}$ \\
\hline 7.5 & $0.0287 \mathrm{ab}$ & $0.833 \mathrm{~b}$ & $0.034 \mathrm{ab}$ & $0.193 \mathrm{ab}$ \\
\hline 11.3 & $0.0316 \mathrm{a}$ & $0.833 \mathrm{~b}$ & $0.036 \mathrm{ab}$ & $0.170 \mathrm{~b}$ \\
\hline 12.5 & $0.0335 \mathrm{a}$ & $0.777 \mathrm{~b}$ & $0.035 \mathrm{ab}$ & $0.172 \mathrm{~b}$ \\
\hline 16.0 & $0.0306 \mathrm{a}$ & $0.710 \mathrm{~b}$ & $0.033 \mathrm{~b}$ & $0.179 \mathrm{~b}$ \\
\hline Significance $^{z}$ & $*$ & * & $* * *$ & $* *$ \\
\hline
\end{tabular}

${ }^{2}$ Significance was established using a one-way analysis using OriginPro 9.1. Means comparisons were established with post hoc Tukey test.

Means in a column followed by the same letter are not statistically different at $P<0.05$.

Ns, $*, * *, * * *$ Nonsignificant or significant at $\mathrm{P} \leq 0.05,0.01$, or 0.001 , respectively.

number of flower clusters per tree (over 300) was found when trees had the lowest crop load the previous year $\left(4.7 \mathrm{fruit} / \mathrm{cm}^{2}\right)$. In general, the number of flower clusters decreased with increasing crop load, although there were no statistical differences among crop loads of 7.5 to 16.0 fruit $/ \mathrm{cm}^{2}$ (Table 5). However, there was large variability among trees in flower induction. Similarly, Robinson and Watkins (2003) observed high tree-to-tree variability in

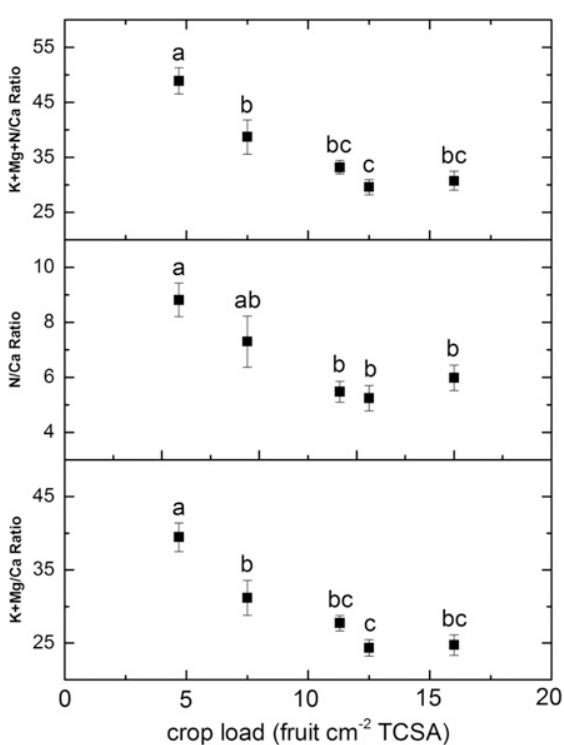

Fig. 5. $(\mathrm{K}+\mathrm{Mg}+\mathrm{N}): \mathrm{Ca}, \mathrm{N}: \mathrm{Ca}$ and $(\mathrm{K}+\mathrm{Mg})$ : $\mathrm{Ca}$ for 'Honeycrisp' apple fruit grown in the northwestern United States thinned to crop loads of 4.7 to 16 fruit cm-2 trunk cross-sectional area. Ns, $*, * *, * * *$ Nonsignificant or significant at $P \leq 0.05,0.01$, or 0.001 , respectively.

flower induction in a corresponding crop load study. For trees that had 7.5 fruit $/ \mathrm{cm}^{2}$, the total number of flower clusters per tree was significantly less than trees that had $4.7 \mathrm{fruit} / \mathrm{cm}^{2}$. The lowest number of flower clusters per tree was 29 for the highest crop load (16.0 fruit/ $\mathrm{cm}^{2}$ ). Blossom cluster density (cluster/TCSA) for trees with crop loads of 4.7 fruit $/ \mathrm{cm}^{2}$ was significantly different from the other four crop loads (Table 5). Following a similar pattern, Robinson and Watkins (2003) reported that flower bud formation was inhibited with crop loads greater than $9 \mathrm{fruit} / \mathrm{cm}^{2}$. Biennial bearing is linked to the number of seeds produced by the tree during the previous year production. Flower initiation for the following year is influenced by gibberellins present in the seeds of the previous yield (Wilkie et al., 2008). The year after treatments were applied, TCSA and tree height were not significantly different among the crop loads (Table 5). Flower initiation was lower in crop loads equal to or higher than 11.3 fruit $/ \mathrm{cm}^{2}$ compared with the lowest crop load $\left(4.7 \mathrm{fruit} / \mathrm{cm}^{2}\right)$ $(P=0.0035)$. The difference in fruit set between crop loads of 4.7 and 16.0 fruit $/ \mathrm{cm}^{2}$ was 347 fruitlets/tree.

\section{Conclusions}

'Honeycrisp' is one of the major apples produced in the regions of Pacific Northwest of the United States and planted acreage is rapidly increasing. For 'Honeycrisp', tartness, crispness, and color are important attributes for consumer preference (Baugher and Schupp, 2010). In the present study, the lowest crop load levels (4.7 and $7.5 \mathrm{fruit} / \mathrm{cm}^{2}$ TSCA) for 'Honeycrisp' apple produced superior fruit quality as indicated by 
Table 5. Effect of crop load on return bloom attitude and fruit set of the following year (2015) for 'Honeycrisp' apple fruit grown in the northwest United States.

\begin{tabular}{lccccc}
\hline $\begin{array}{l}\text { Crop load (no. } \\
\text { fruit/ } \mathrm{cm}^{2} \text { TCSA) }\end{array}$ & TCSA $^{\mathrm{z}}\left(\mathrm{cm}^{2}\right)$ & Tree ht $(\mathrm{cm})$ & No. cluster/tree & $\begin{array}{c}\text { Blossom density } \\
(\text { cluster/TCSA cm })\end{array}$ & $\begin{array}{c}\text { No. of fruit } \\
\text { set/tree }\end{array}$ \\
\hline 4.7 & 8.09 & 326.3 & $309.7 \mathrm{a}$ & $38.14 \mathrm{a}$ & $396.0 \mathrm{a}$ \\
7.5 & 6.87 & 328.7 & $109.7 \mathrm{~b}$ & $15.68 \mathrm{~b}$ & $187.3 \mathrm{ab}$ \\
11.3 & 7.83 & 297.0 & $37.3 \mathrm{~b}$ & $4.81 \mathrm{~b}$ & $86.0 \mathrm{~b}$ \\
12.5 & 8.05 & 300.7 & $53.0 \mathrm{~b}$ & $6.79 \mathrm{~b}$ & $100.3 \mathrm{~b}$ \\
16.0 & 7.47 & 315.7 & $28.7 \mathrm{~b}$ & $4.28 \mathrm{~b}$ & $48.7 \mathrm{~b}$ \\
Significance $^{\mathrm{z}}$ & NS & NS & $* *$ & $* *$ & $* *$ \\
\hline
\end{tabular}

${ }^{2}$ Significance was established with proc GLM in SAS, type III sums of squares. Means comparisons were established with post hoc Tukey test.

Means in a column followed by the same letter are not statistically different at $P<0.05$.

Ns, *,**, *** Nonsignificant or significant at $P \leq 0.05,0.01$, or 0.001 , respectively.

increased firmness, dry matter soluble solids content, and TA. These quality traits were maintained through storage indicating that high preharvest quality results in fruit with longer storability. Fruit overcolor (percentage of red area on the peel) was also higher in the lowest crop loads. Crop loads above 11-12 fruit $/ \mathrm{cm}^{2}$ can compromise fruit quality. $I_{\mathrm{AD}}$, an index correlated with the outer mesocarp chlorophyll content, measured using a DA-meter, was able to discriminate the ripening stage of the fruit. High crop loads delayed ripening and resulted in poor color formation. Using the $I_{\mathrm{AD}}$ index has potential to optimize harvest timing and make informed storage duration decisions according to the fruit maturity and quality at harvest. To achieve high productivity over the entire life of an orchard, 'Honeycrisp' requires careful crop load management. High crop loads, especially in young orchards, can dramatically reduce flower bud formation the following year and lead to biennial bearing. Here, we demonstrate a strong relationship between crop load and fruit yield, quality and future productivity that highlights the importance of precise management of crop loads to optimize quality, storability, and future productivity in 'Honeycrisp' orchards.

\section{Literature Cited}

Alcobendas, R., J.M. Mirás-Avalos, J.J. Alarcón, F. Pedrero, and E. Nicolás. 2012. Combined effects of irrigation, crop load and fruit position on size, color and firmness of fruits in an extraearly cultivar of peach. Sci. Hort. 142:128-135.

Avery, D.J. 1975. Effects of fruits on photosynthetic efficiency, p. 110-112. In: H.C. Pereira (ed.). Climate and the orchard. CABI, Farnham Royal, Slough, United Kingdom.

Awad, M.A., A. De Jager, M. Dekker, and W.M. Jongen. 2001. Formation of flavonoids and chlorogenic acid in apples as affected by crop load. Sci. Hort. 91(3):227-237.

Bain, I.M. and R.N. Robertson. 1951. The physiology of growth in apple fruit. Aust. J. Sci. Res. 4:75-91.

Bangerth, F. 1979. Calcium-related physiological disorders of plants. Annu. Rev. Phytopathol. 17(1):97-122.

Baugher, T.A. and J.R. Schupp. 2010. Relationship between 'Honeycrisp' crop load and sensory panel evaluations of the fruit. Journal of the American Pomological Society 64(4):226233.

Bergh, O. 1990. Effect of time of hand-thinning on apple fruit size. S. Afr. J. Plant Soil 7(1):1-10.
Castro, D.C., N. Álvarez, P. Gabriel, N. Micheloud, M. Buyatti, and N. Gariglio. 2015. Crop loading studies on 'Caricia' and 'Eva' apples grown in a mild winter area. Scientia Agricola 72(3):237-244.

Crassweller, R., R. McNew, A. Azarenko, B. Barrit, R.G. Beldin, L. Berkett, S. Brown, J. Clemens, J. Cline, W. Cowgill, D. Ferree, E. Garcia, D. Greene, G. Greene, C. Hampson, I. Merwin, D. Miller, S. Miller, R. Moran, J. Obermiller, D. Rosenberger, T. Rom, T. Roper, J. Schupp, and E. Stover. 2005. Performance of apple cultivars in the 1995 NE-183 regional project planting: I. Growth and yield characteristics. J. Amer. Pomol. Soc. 59:18-27.

DeLong, J., R. Prange, P. Harrison, D. Nichols, and H. Wright. 2014. Determination of optimal harvest boundaries for Honeycrisp ${ }^{\mathrm{TM}}$ fruit using a new chlorophyll meter. Can. J. Plant Sci. 94:361-369.

Denne, P.M. 1960. The growth of apple fruitlets and the effect of early thinning on fruit development. Ann. Bot. 24:397-406.

Dennis, F., Jr. 2000. The history of fruit thinning. Plant Growth Regulat. 31:1-16.

Embree, C.G., M.T.D. Myra, D.S. Nichols, and A.H. Wright. 2007. Effect of blossom density and crop load on growth, fruit quality, and return bloom in Honeycrisp' apple. HortScience 42:1622-1625.

Embree, C.G. and D.S. Nichols. 2005. Bioregulators improve fruit size and color and reduce crop load and annual bearing of Honeycrisp apples. Can. J. Plant Sci. 85:453-455.

Faust, M. and C.B. Shear. 1968. Corking disorders of apples: A physiological and biochemical review. Bot. Rev. 34:441-469.

Faragher, J.D. and R.L. Brohier. 1984. Anthocyanin accumulation in apple skin during ripening: Regulation by ethylene and phenylalanine ammonia-lyase. Sci. Hort. 22:89-96.

Ferguson, I.B. and C.B. Watkins. 1989. Bitter pit in apple fruit. Hort. Rev. 11:289-355.

Ferguson, I.B. and C.B. Watkins. 1992. Crop load affects mineral concentrations and incidence of bitter pit in 'Cox's Orange Pippin' apple fruit. J. Amer. Soc. Hort. Sci. 117:373-376.

Gamble, J., F.R. Harker, Sr., S.R. Jaeger, A. White, C. Bava, M. Beresford, and A. Woolf. 2010 The impact of dry matter, ripeness and internal defects on consumer perceptions of avocado quality and intentions to purchase. Postharvest Biol. Technol. 57(1):35-43.

Glover, J.D., J.P. Reganold, and P.K. Andrews. 2000 . Systematic method for rating soil quality of conventional, organic, and integrated apple orchards in Washington State. Agr. Ecosyst. Environ. 80(1):29-45.

Hampson, C.R. and H. Kemp. 2003. Characteristics of important commercial apple cultivars. $p$. 61-90. In: D.D. Ferree, and I.J. Warrington (eds.). Apples, botany, production and uses. CABI, Wallingford, UK.
Hanrahan, I. 2012. Starch Iodine Index Honeycrisp. Washington Tree Fruit Research Commission. 24 Apr. 2015. <http://www.treefruitresearch.com/ resources-a-downloads/starch-iodine-index-forhoneycrisp>.

Harker, F.R., B.T. Carr, M. Lenjo, E.A. MacRae, W.V. Wismer, K.B. Marsh, and R.B. Pereira. 2009. Consumer liking for kiwifruit flavour: A meta-analysis of five studies on fruit quality. Food Qual. Prefer. 20(1):30-41.

Heim, G., J.J. Landsberg, R.L. Watson, and P. Brain. 1979. Ecophysiology of apple trees; dry matter production and partitioning in young 'Golden Delicious' apple trees. J. Appl. Ecol. 16:179-194.

Link, H. 2000. Significance of flower and fruit thinning on fruit quality. Plant Growth Regulat. 31:17-26.

Luby, J. and D.S. Bedford. 1990. Honeycrisp apple. Regents of the University of Minnesota. U.S. Patent PP7, 197. International Classification A01H 005/00.

Mann, H., D. Bedford, J. Luby, Z. Vickers, and C. Tong. 2005. Relationship of instrumental and sensory texture measurements of fresh and stored apples to cell number and size. HortScience 40:1815-1820.

McGuire, R. 1992. Reporting of objective color measurements. HortScience 27:1254-1255.

Nichols, D. and H. Wright. 2003. How to grow 'Honeycrisp' apples for success. Nova Scotia Fruit Growers' Association: 140th Annual Report 2003. NSFGA, Kentville, Nova Scotia, Canada.

Núñez-Delicado, E., M. Serrano-Megías, A.J. PérezLópez, and J.M. López-Nicolás. 2005. Polyphenol Oxidase from Dominga Table Grape. J. Agr. Food Chem. 53:6087-6093.

Palmer, J.W. 1992. Effects of varying crop load on photosynthesis, dry matter production and partitioning of Crispin/M.27 apple trees. Tree Physiol. 11:19-33.

Palmer, J.W., R. Giuliani, and H. Adams. 1997. Effect of crop load on fruiting and leaf photosynthesis of 'Braeburn'/M. 26 apple trees. Tree Physiol. 17:741-746.

Palmer, J.W., F.R. Harker, S. Tustin, and J. Johnston. 2010. Fruit dry matter concentration: A new quality metric for apples. J. Sci. Food Agr. 90:2586-2594.

Pellerin, B.P., D. Buszard, A. Georgallas, and R.J. Nowakowski. 2012. A novel framework to consider endogenous hormonal control of apple tree flowering. HortScience 47:589592.

Pellerin, B.P., D. Buszard, D. Iron, C.G. Embree, R.P. Marini, D.S. Nichols, and D. Neilsen. 2011. A theory of blossom thinning to consider maximum annual flower bud numbers on biennial apple trees. HortScience 46:40-42.

Robinson, T.L. and C.B. Watkins. 2003. Crop load of 'Honeycrisp' affects not only fruit size but many quality attributes. New York Fruit Q 11(3):7-10.

Robinson, T.L. and S.L. Watkins. 2009. Cropload and nutrition affect Honeycrisp apple quality. New York Fruit Q 17(2):24-28.

Rosenberger, D.A., J.R. Schupp, S.A. Hoying, L. Cheng, and C.B. Watkins. 2004. Controlling bitter pit in 'Honeycrisp' apples. HortTechnology 14:342-349.

Saranwong, S., J. Sornsrivichai, and S. Kawano. 2004. Prediction of ripe-stage eating quality of mango fruit from its harvest quality measured nondestructively by near infrared spectroscopy. Postharvest Biol. Technol. 31(2):137-145. 
Tong, C.B.S., D.S. Bedford, J.J. Luby, F.M. Propsom, J.P. Mattheis, C.B. Watkins, and S.A. Weis. 2003. Location and temperature effects on soft scald in 'Honeycrisp' apples. HortScience 38:1153-1155.

Wargo, J.M. and C.B. Watkins. 2004. Maturity and storage quality of 'Honeycrisp' apples. HortTechnology 14:496-499.

Watkins, C.B., M. Erkan, and J.F. Nock. 2005. Harvest date effects on maturity, quality, and storage disorders of 'Honeycrisp' apples. HortScience 40:164-169.
Watkins, C.B. and J.F. Nock. 2012. Controlledatmosphere storage of 'Honeycrisp' apples. HortScience 47:886-892.

Wertheim, S.J. 2000. Developments in the chemical thinning of apple and pear. Plant Growth Regulat. 31:85-100.

Wilkie, J.D., M. Sedgley, and T. Olesen. 2008. Regulation of floral initiation in horticultural trees. J. Expt. Bot. 59(12):3215-3228.

Wright, A.H., C.G. Embree, D.S. Nichols, R.K Prange, P.A. Harrison, and J.M. DeLong. 2006. Fruit mass, colour and yield of
'Honeycrisp'тм apples are influenced by manually-adjusted fruit population and tree form. J. Hort. Sci. Biotechnol. 81(3):397401.

Wünsche, J. and I.B. Ferguson. 2005. Crop load interactions in apple. Hort. Rev. 31:231-290.

Ziosi, V., M. Noferini, G. Fiori, A. Tadiello, L. Trainotti, G. Casadoro, and G. Costa. 2008. A new index based on vis spectroscopy to characterize the progression of ripening in peach fruit. Postharvest Biol. Technol. 49:319-329. 


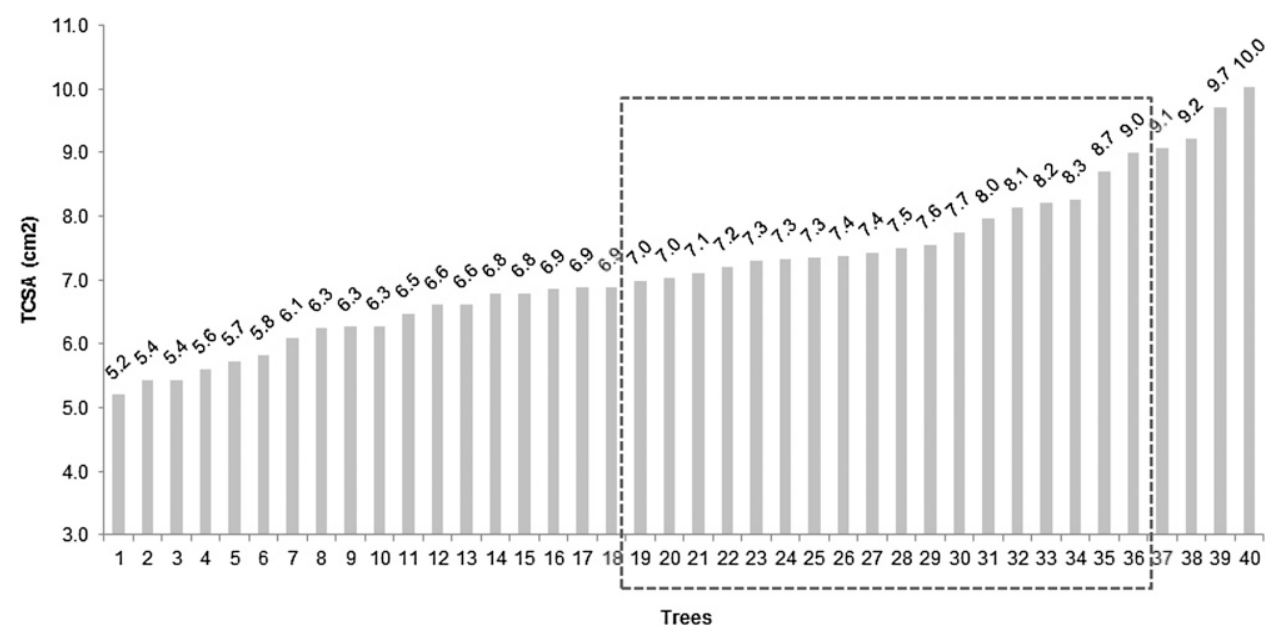

Supplemental Fig. 1. Trunk cross sectional area (TCSA) measured on 40 trees show the variability of the block. Fifteen homogeneous trees were selected with a trunk cross sectional area between 7 and $9 \mathrm{~cm}^{2}$ for the present trial. (In the rectangular are highlighted 18 trees in this range of TCSA.)

Supplemental Table 1. Incidence of postharvest disorders, irregularities in fruit shape, and patterns in fruit color according to crop load for 'Honeycrisp' apple fruit grown in the northwest United States.

\begin{tabular}{|c|c|c|c|c|c|c|c|c|c|c|c|c|}
\hline $\begin{array}{l}\text { Cropload (number } \\
\text { fruit } / \mathrm{cm}^{2} \text { TCSA) }\end{array}$ & Solid & Striped & Mottle & Asymmetry & Not round & Russetting & $\begin{array}{l}\text { Bitter } \\
\text { pit }\end{array}$ & $\begin{array}{l}\text { Soft } \\
\text { scald }\end{array}$ & $\begin{array}{l}\text { Lenticel } \\
\text { browning }\end{array}$ & Rot & Greasiness & $\begin{array}{c}\text { Count } \\
\text { (number } \\
\text { of fruit } \\
\text { assessed) }\end{array}$ \\
\hline 4.7 & 3 & 20 & 14 & 9 & 8 & 0 & 0 & 0 & 0 & 2 & 1 & 26 \\
\hline 7.5 & 13 & 6 & 6 & 12 & 2 & 0 & 0 & 0 & 0 & 2 & 0 & 24 \\
\hline 11.3 & 3 & 28 & 5 & 18 & 4 & 1 & 0 & 0 & 0 & 2 & 0 & 34 \\
\hline 12.5 & 0 & 27 & 0 & 14 & 2 & 0 & 0 & 0 & 0 & 2 & 0 & 27 \\
\hline 16.0 & 8 & 11 & 4 & 6 & 1 & 0 & 0 & 0 & 0 & 3 & 0 & 24 \\
\hline \multicolumn{13}{|c|}{ Statistical analysis of postharvest disorders ${ }^{\mathrm{z}}$} \\
\hline 4.7 & 0.9407 & 0.9468 & 0.9164 & 0.3272 & 0.0041 & 0.9887 & - & - & - & 0.8771 & 0.9017 & \\
\hline 7.5 & 0.9081 & 0.8897 & 0.9437 & 0.4534 & 0.686 & 0.9891 & - & - & - & 0.9829 & 0.989 & \\
\hline 11.3 & 0.9601 & 0.999 & 0.966 & 0.1069 & 0.5191 & 0.9029 & - & - & - & 0.7812 & 0.9883 & \\
\hline 12.5 & 0.9607 & 0.937 & 0.9452 & 0.3204 & 0.5477 & 0.9886 & - & - & - & 0.8279 & 0.9885 & \\
\hline 16.0 & 0.9106 & 0.9169 & 0.9197 & 0.1372 & $<0.0001$ & 0.8637 & - & - & - & $<0.0001$ & 0.8634 & \\
\hline
\end{tabular}

${ }^{2}$ Significance was established with proc logistic in SAS via analysis of maximum likelihood estimates (Chi-square). 
Supplemental Table 2. Statistical analysis of experimental factors storage time, crop load, and $I_{\mathrm{AD}}$ classification on measures of fruit quality and maturity. Main effects and means comparisons are further elaborated for storage time (Supplemental Table 4), as well as crop load and $I_{A D}$ at each storage time point (Tables 2 and 3) for 'Honeycrisp' apple fruit grown in the northwest United States.

\begin{tabular}{|c|c|c|c|c|c|c|c|c|c|c|c|c|c|c|c|}
\hline & $\begin{array}{c}\text { Wt } \\
\text { drop } \\
(\mathrm{T} 1-\mathrm{T} 0)\end{array}$ & $\begin{array}{c}\text { DA } \\
\text { drop } \\
(\mathrm{T} 1-\mathrm{T} 0)\end{array}$ & $\begin{array}{c}\text { Intensity } \\
\text { of red } \\
\text { (only at } \\
\text { T1) }\end{array}$ & $\begin{array}{l}\text { Wt } \\
\text { at } \\
\text { harvest } \\
(\mathrm{g})\end{array}$ & $\begin{array}{l}\mathrm{I}_{A D} \\
\text { harvest } \quad \mathrm{S}\end{array}$ & Starch & $\begin{array}{c}\mathrm{Ht} \\
(\mathrm{mm})\end{array}$ & $\begin{array}{lr}\text { Width } & \mathrm{Ht} \\
(\mathrm{mm}) & \mathrm{I}\end{array}$ & $\begin{array}{l}\text { It:width } \\
\text { ratio }\end{array}$ & $\begin{array}{l}\text { Firmness } \\
\left(\mathrm{kg} / \mathrm{cm}^{2}\right)\end{array}$ & IEC $(\mu \mathrm{mol})^{\mathrm{z}}$ & $\begin{array}{c}\text { SSC } \\
\text { (Brix) }\end{array}$ & $\mathrm{pH}^{\mathrm{y}}$ & $\mathrm{TA}^{\mathrm{y}}$ & $\begin{array}{c}\begin{array}{c}\text { Dry } \\
\text { matter }\end{array} \\
(\mathrm{DM} \%)^{\mathrm{x}} \\
\end{array}$ \\
\hline $\begin{array}{c}\begin{array}{c}\text { Overall } \\
\text { model }^{\mathrm{x}}\end{array}\end{array}$ & $* * *$ & $* * *$ & $* * *$ & $* * *$ & $* * *$ & $* * *$ & $* * *$ & $* * *$ & *** & $* * *$ & $* * *$ & $* * *$ & $* * *$ & $* * *$ & $* * *$ \\
\hline $\begin{array}{l}\text { Storage } \\
\text { time }\end{array}$ & . & . & . & $* *$ & NS & $* * *$ & $*$ & NS & * & NS & $* * *$ & NS & NS & $* * *$ & $*$ \\
\hline Cropload & $* * *$ & NS & $* * *$ & $* * *$ & $* * *$ & $* *$ & $* * *$ & $* * *$ & $* * *$ & $* * *$ & $* * *$ & $* * *$ & $*$ & $* * *$ & $* * *$ \\
\hline $\begin{array}{l}\text { Storage } \\
\text { time* cropload }\end{array}$ & . & . & . & NS & NS & $* * *$ & $*$ & NS & NS & * & $* * *$ & $* * *$ & NS & $* * *$ & NS \\
\hline $\begin{array}{l}\text { Storage time*DA } \\
\text { class }\end{array}$ & . & . & . & NS & NS & $* * *$ & NS & NS & NS & NS & NS & $* *$ & $* * *$ & NS & NS \\
\hline $\begin{array}{l}\text { Cropload*DA } \\
\text { class }\end{array}$ & NS & NS & NS & $* *$ & NS & $* *$ & NS & $* *$ & NS & NS & $* *$ & $* *$ & NS & NS & NS \\
\hline Storage time* & . & . & . & NS & NS & $* *$ & NS & NS & NS & NS & $* *$ & NS & NS & NS & NS \\
\hline & Overcolor & $\begin{array}{c}\mathrm{L} \\
\text { overcolor }\end{array}$ & $\begin{array}{c}\text { a } \\
\text { overcolor }\end{array}$ & $\begin{array}{c}\mathrm{b} \\
\text { overcolor }\end{array}$ & \multicolumn{2}{|c|}{$\begin{array}{l}\text { Overcolor } \\
\text { hue angle }\end{array}$} & $\begin{array}{l}\text { vercolor } \\
\text { chroma }\end{array}$ & $\begin{array}{c}\mathrm{L} \\
\text { backgroun }\end{array}$ & and back & $\begin{array}{l}\text { a } \\
\text { kground }\end{array}$ & $\begin{array}{c}\mathrm{b} \\
\text { background }\end{array}$ & \multicolumn{2}{|c|}{$\begin{array}{l}\text { background } \\
\text { hue angle }\end{array}$} & \multicolumn{2}{|c|}{$\begin{array}{c}\text { background } \\
\text { chroma }\end{array}$} \\
\hline Overall model $^{\mathrm{x}}$ & $* * *$ & $* * *$ & $* * *$ & $* * *$ & \multicolumn{2}{|c|}{$* * *$} & $* * *$ & NS & & $* * *$ & $* * *$ & & $* *$ & & $* * *$ \\
\hline Storage time & NS & $*$ & NS & $* * *$ & \multicolumn{2}{|l|}{ NS } & $* * *$ & NS & & $* * *$ & $* * *$ & & ** & & $* * *$ \\
\hline Cropload & $* * *$ & $* * *$ & $* * *$ & $* * *$ & \multicolumn{2}{|l|}{$* * *$} & $* * *$ & NS & & $* *$ & $* * *$ & & ** & & $* *$ \\
\hline DA class & $* * *$ & $* * *$ & $* * *$ & $* * *$ & \multicolumn{2}{|l|}{$* * *$} & $* * *$ & NS & & $* * *$ & $* * *$ & & ** & & $* * *$ \\
\hline $\begin{array}{l}\text { Storage time* } \\
\text { cropload }\end{array}$ & NS & NS & NS & $*$ & \multicolumn{2}{|l|}{ NS } & $* *$ & NS & & NS & $*$ & & NS & & $*$ \\
\hline $\begin{array}{c}\text { Storage time* } \\
\text { DA class }\end{array}$ & NS & NS & NS & NS & \multicolumn{2}{|l|}{ NS } & NS & NS & & NS & NS & & Ns & & NS \\
\hline $\begin{array}{l}\text { Cropload* } \\
\text { DA class }\end{array}$ & NS & NS & NS & NS & \multicolumn{2}{|l|}{ NS } & $*$ & NS & & * & NS & & * & & NS \\
\hline $\begin{array}{l}\text { Storage time* } \\
\text { cropload }{ }^{*} \mathrm{DA} \\
\text { class }\end{array}$ & NS & NS & NS & NS & \multicolumn{2}{|l|}{ NS } & NS & NS & & NS & NS & & NS & & NS \\
\hline
\end{tabular}

${ }^{\mathrm{z} I E C}$, internal ethylene concentration.

${ }^{\mathrm{y}} \mathrm{pH}$, TA and DM\% were analyzed independently due to differing numbers of replication.

${ }^{\mathrm{x}}$ Significance was established with proc GLM in SAS, type III sums of squares.

Ns, ***, **** Nonsignificant or significant at $P \leq 0.05,0.01$, or 0.001 , respectively.

Supplemental Table 3. Post hoc means comparisons of main effect storage time with Tukey's honest significant difference (HSD) for 'Honeycrisp' apple fruit grown in the northwest United States.

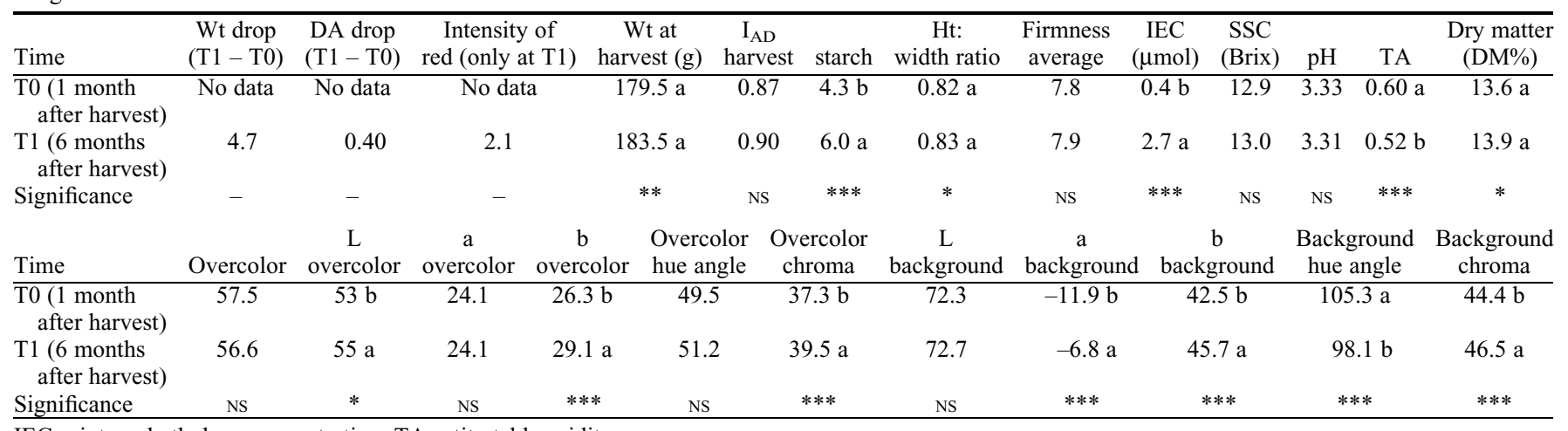

IEC = internal ethylene concentration; TA = titratable acidity.

Significance was established with proc GLM in SAS, type III sums of squares.

Ns, *,**, *** Nonsignificant or significant at $P \leq 0.05,0.01$, or 0.001 , respectively. 